\title{
The Molecular Basis and Clinical Management of Ataxia Telangiectasia
}

\author{
Sian D. Spacey, Richard A. Gatti and Gwyn Bebb
}

\begin{abstract}
The unique combination of phenotypic manifestations seen in ataxia telangiectasia (AT) has intrigued neurologists, oncologists, radiation biologists and immunologists for several decades. Initially, the primary care givers of AT patients are often pediatricians but neurologists will inevitably become involved in their care. Over the last few years great strides have been made in understanding the genetic basis of this disease but useful therapeutic interventions are still not available. In this article, we review the clinical features and the current understanding of the pathophysiology of the syndrome. In addition, we address issues related to genetic counseling, prenatal diagnosis, screening and implications for AT heterozygotes.
\end{abstract}

RÉSUMÉ: Fondement moléculaire et prise en charge clinique de l'ataxie-télangiectasie. La combinaison unique des manifestations phénotypiques observée dans l'ataxie-télangiectasie (AT) a intrigué les neurologues, les oncologues, les radiobiologistes et les immunologistes depuis plusieurs décennies. Initialement, les principaux dispensateurs de soins à ces patients sont souvent les pédiatres, mais les neurologues sont inévitablement impliqués. $\mathrm{Au}$ cours des dernières années, des progrès importants ont été réalisés dans la compréhension du fondement génétique de cette maladie, mais il n'existe pas encore de traitement. Nous revoyons les manifestations cliniques et les connaissances actuelles de la physiopathologie de ce syndrome. De plus, nous discutons des questions relatives au conseil génétique, au diagnostic prénatal, au dépistage et aux implications pour les hétérozygotes.

Can. J. Neurol. Sci. 2000; 27: 184-191

Of the hereditary ataxias, one of the most intriguing is that first identified by Syllaba and Henner in $1926,{ }^{1}$ and further described by Louis-Bar in $1941 .^{2}$ Its detailed description and labeling as ataxia telangiectasia (AT) by Boder and Sedgwick in $1958^{3}$ launched the modern era of AT research. AT is a rare syndrome broadly distributed throughout the world, although there are areas and specific populations where it is more highly concentrated, notably in countries with high in-breeding coefficients, such as Turkey, Norway, Costa Rica, Iran, Saudi Arabia, among North African Jews and South African Scots. Inherited in an autosomal recessive fashion, its incidence is estimated to be somewhere between 1:50,000 and 1:400,000 live births. The frequency of the AT gene in the general population in North America is estimated at about 1\%.5 There are no clear statistics on the incidence of the syndrome in Canada, but areas of high concentration have been documented among the Mennonites of the Alberta/British Columbia border. ${ }^{4}$

\section{Clinical features: NeUrological}

AT is characterized by five cardinal features, ataxia, oculocutaneous telangectasia, immunodeficiency, cancer predisposition and a hypersensitivity to ionizing radiation. The clinical hallmark of AT, and present in all cases, is the progressive cerebellar ataxia. Mainly a truncal ataxia, it is usually the first presenting symptom, becoming manifest at about two years of age and culminating with the affected individual becoming wheelchair bound by their early teens. ${ }^{6}$ The phenotype is also characterized by oculomotor apraxia, an impassive facies, a tendency to drool and slow, slurred speech. ${ }^{7}$ Often this is mistaken for cerebral palsy or mental retardation but most AT individuals seem to have a normal IQ. ${ }^{8}$ Motor dysfunction is variable, often a combination of ataxia, dystonia and chorea. A peripheral axonal neuropathy is common and is manifested by decreased deep tendon reflexes. ${ }^{9,10}$ An electrophysiological study of five Chinese AT patients demonstrated axonal neuropathy in all cases with the earliest detection at six years. Two patients demonstrated mild degenerative changes on electromyography. ${ }^{9}$ A case study of an AT patient with a sensory neuropathy reported loss of fibres, particularly large ones, axonal degenerative changes, Schwann cell inclusions of various types and rare signs of primary

From Neurogenetics, Institute of Neurology, Queen Square, London, UK, (SDS); the Department of Pathology, School of Medicine, University of California, Los Angeles, California, USA(RAG); and the Department of Medicine, University of British Columbia, and the Department of Advanced Therapeutics, BC Cancer Research Centre, Vancouver, BC, Canada (GB).

ReCeived SePtember 13, 1999. AcCePted infinalform February 29, 2000 Reprint requests to: Sian D Spacey, Neurogenetics, Institute of Neurology, Queen Square, London, UK, WC1N 3BG 
demyelination. Teased fiber study showed paranodal myelin enlargements, segmental demyelination, shortening and/or variability of internodal length. ${ }^{10,13}$

The second cardinal feature, the oculocutaneous telangiectasia, develops later than the ataxia with a mean age of onset at 72 months ${ }^{11}$ but sometimes appearing as late as 10 years of age. ${ }^{12}$ The telangiectasia can appear over the body, the external ear, creases and vee of the neck and the antecubital and popliteal fossa. On the conjunctiva, the telangiectasia give the eyes a "bloodshot" appearance, distributing symmetrically on the conjunctiva as fine, bright, red streaks. This helpful dermatological finding can disappear later in life.

\section{Clinical features: NON-NeUROlogical}

One-third of AT patients have a severe immune deficiency characterized by absent or low levels of $\operatorname{IgA}$ and $\operatorname{IgG} 2$ with decreased responsiveness to skin antigens underpinned by an atrophic or absent thymus at postmortem. ${ }^{14-16}$ The recurrent sinopulmonary infections, which occasionally evolve into bronchiolitis obliterans ${ }^{17}$ and cause so much of the morbidity and mortality associated with AT, are often attributed to this immune deficiency. However, the inconsistent nature and poor correlation between immune deficiency and morbidity suggests that bulbar dysfunction and recurrent aspiration may be a major contributor. ${ }^{18}$

The most tragic manifestation of AT, however, is the cancer predisposition associated with it. The lifetime frequency of cancer in AT patients approaches 38\%, with 1 in 20 developing more than one malignancy. Malignancy alone or in combination

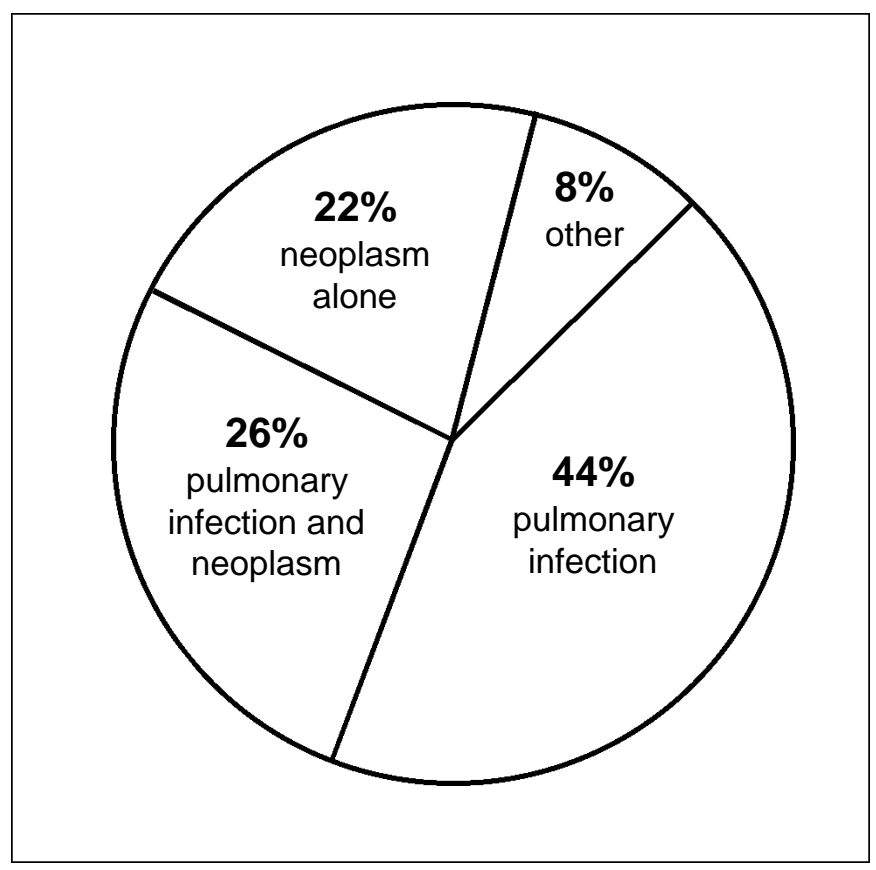

Figure 1: Cause of Death in Ataxia Telangiectasia Patients based on Morrell, Chase, Swift, $1990^{20}$ and Taylor et al., $1996^{21}$

Despite the high incidence of malignancy, the major cause of mortality in AT patients is pulmonary infection, which in combination with malignancy accounts for almost three-quarters of all deaths. with sino-pulmonary infection accounts for almost half of all AT deaths (Figure 1). ${ }^{19-21}$ Lymphoreticular malignancies (mainly $\mathrm{T}$ cell) predominate in the first two decades, solid tumours thereafter. The most intriguing feature of AT is the radiation sensitivity, which renders affected individuals particularly sensitive to therapeutic doses of ionizing radiation, complicating the management of any malignancy. ${ }^{22,23}$ It is presently unclear whether the cancer predisposition is a consequence of the immune deficiency or of the inefficient handling of double strand DNAbreaks that underlies the radiation sensitivity. Finally, some AT individuals display gonadal atrophy and are assumed to be sterile. However, the majority of AT patients develop normal secondary sexual characteristics.

The diagnosis of AT is not immediately obvious in the early stages when the ataxia is present but the telangiectasia are not. In fact, in one study, the median age of diagnosis was 78 months. ${ }^{12}$ In two thirds of these cases the diagnosis was made only after both ataxia and telangiectasia were present. In that study, the most common misdiagnosis was cerebral palsy followed by ataxia of unknown origin. It appeared that physicians relied heavily on the appearance of telangiectasia before they made the diagnosis. The inexpensive alpha-feto protein test, discussed later in this paper, would allow for early diagnosis and can be justified in most patients who present with early onset ataxia of unknown cause. AT can be distinguished from other autosomal recessive ataxias such as Friedrich's Ataxia (FA) by an earlier age of onset of cerebellar symptoms and the presence of dystonia and chorea later on in the teens (see Table). Unlike AT, FA patients have pyramidal weakness of the legs, extensor plantar responses and symptoms related to posterior column involvement. ${ }^{11}$ Non-neurological signs and symptoms can also help to distinguish these two autosomal recessive ataxias. In addition to telangiectasia, AT is marked by recurrent sinopulmonary infections and a predisposition to malignancy while FA is associated with kyphoscoliosis, foot deformities, diabetes and cardiomyopathy. Lastly, genetic testing can distinguish between the two.

\section{Pathological findings}

It has been assumed that the signs pathognomonic of AT are related primarily to changes in the cerebellar cortex. Atrophy of the cerebellar folia and vermis are consistent findings at autopsy in AT patients and are confirmed by in vivo CTand MRI imaging studies. ${ }^{24}$ Examination of the cerebellum by light microscopy shows severe Purkinje cell loss, thinning of the internal granulocyte layer and marked separation of the molecular and granular layer by the Golgi epithelial cell layer. ${ }^{25}$ The number of Purkinje cells per $1000 \mu \mathrm{m}$ was reduced but the number of Golgi epithelial cells increased. Analysis of the Purkinje neurons reveals abnormally smooth dendrites with reduced arborization and occasional displacement of the soma to within the molecular layer. Electron microscopy demonstrates dark degeneration of Purkinje cell dendrites. ${ }^{26-28}$ However, normal terminals remain in contact with the crenated shafts of these dendrites. Cortical interneurones and the ultrastructure of the granular cell layer is normal. These findings are consistent with a continuous process of Purkinje cell loss. However, this does not guarantee that the central lesion of AT is in this cell layer. ${ }^{29}$ 
Pathological features are not limited to the cerebellum. In a series of patients, Aguilar et al ${ }^{26}$ described chronic degeneration of the dentate and olivary nucleus, and neuro axonal dystrophy in the tegmentum of the medulla oblongata. Changes were also seen in the spinal cord with demyelination of the posterior columns, dystrophic and degenerative changes of the anterior horn cells and neuromelanosis with ballooning degeneration of the neurons in spinal ganglia.

\section{IN VITRO CHARACTERISTICS}

Many of the clinical hallmarks of AT are reflected in the in vitro behaviour of cells derived from AT patients. For example, the lymphocyte response to mitogens such as phytohemagglutinin (PHA) is reduced in most patients. In addition, AT cells show increased sensitivity to ionizing radiation and radiomimetic chemicals, displaying aberrant cell cycle checkpoints by continuing on through the cell cycle oblivious to DNA damage that requires repair before the next replication phase. $^{30,31}$ This phenomenon is called radio-resistant DNA synthesis (RDS) and is, in fact, the phenotype on which the assignment of ATpatients to four complementation groups (A, C, D, and E) was based. ${ }^{32,33}$ However, a clinical correlation to the four complementation groups has never been demonstrated.

\section{GENETICS}

Understanding how a single molecular genetic defect could account for the pleiotropic manifestations of AT has been a long-term goal of neurologists, oncologists and radiation biologists - one that may now be within reach. The initial description of AT implied inheritance in an autosomal recessive fashion since parents are never affected. Parents of AT patients are, therefore, obligate heterozygotes, each carrying one defective copy of the gene. Nevertheless, sporadic cases of AT have been described.

\section{Identification of AT mutated (ATM)}

In the late 1980s, the gene for AT was mapped to chromosome $11 \mathrm{q} 22-23$ by Gatti and colleagues ${ }^{34}$ exactly where it was originally suspected that the genes for each of the four complementation groups lay in close proximity to each other. ${ }^{35}$ However, in 1995 , Savitsky et al $^{36}$ using YAC contigs spanning this region, published the partial sequence of a strong candidate gene, which they labeled ATM (AT mutated). Mutations in this gene have been found in more than $90 \%$ of AT patients examined including members of each complementation group. ${ }^{37}$ To date, more than 400 mutations have been documented extending over all 66 exons of the gene. ${ }^{38-41}$

\section{Function of ATM}

Clues to the function of ATM can be gleaned from sequence comparisons with other genes. Once cloned, it was realized that ATM shares sequence homology with the yeast gene rad 3 (which regulates passage through the cell cycle after DNA damage) and with high molecular weight phospho-inositol kinase 3 (PI-3 kinase), an enzyme involved in signal transduction. ${ }^{42-44}$ Genes that share homology with Rad 3 and PI3 kinase include the yeast gene Mec1 (Mitosis entry point 1) which regulates cell cycle checkpoints on induction of DNA damage and the Drosophila gene mei-41. Mei-41 mutants exhibit an increase in chromosomal abnormalities, sensitivity to ultra violet, X-rays and hydroxyurea and reduced meiotic recombination. ${ }^{45}$ The human homologue of Mec1, FRP1 (FRAPrelated protein), has recently been cloned and mapped to chromosome 3q22-q24 and has also been called ATR (AT-

Table: Summary of the Features of Ataxia Telangiectasia and Friedreich's Ataxia

\begin{tabular}{|c|c|c|}
\hline Clinical Feature & Ataxia Telangiectasia & FRIEDREICH'S ATAXIA \\
\hline Main Presentation & - progressive cerebellar truncal ataxia & $\begin{array}{l}\text { - progressive ataxia of gait and limbs, dysarthria } \\
\text { - loss of proprioception and vibratory sense }\end{array}$ \\
\hline Onset of symptom & $2-5 y r s$ & typically before puberty \\
\hline Neurological features & $\begin{array}{l}\text { - ataxia } \\
\text { - decreased deep tendon reflexes } \\
\text { - dystonia and chorea } \\
\text { - sensory neuropathy }\end{array}$ & $\begin{array}{l}\text { - } \text { ataxia } \\
\text { - decreased deep tendon reflexes } \\
\text { - } \text { pyramidal weakness } \\
\text { - extensor plantar response } \\
\text { - loss of proprioception and vibratory sense }\end{array}$ \\
\hline Associated Problems & $\begin{array}{l}\text { - conjunctival and cutaneous telangiectasia } \\
\text { - sino-pulmonary infections } \\
\text { - cancer predisposition } \\
\text { - radiation sensitivity }\end{array}$ & $\begin{array}{l}\text { - kyphoscoliosis } \\
\text { - foot deformities } \\
\text { - diabetes } \\
\text { - cardiomyopathy }\end{array}$ \\
\hline Genetics & $\begin{array}{l}\text { - autosomal recessive } \\
\text { - } 11 \mathrm{q} 22-23 \\
\text { - } \mathrm{ATM}\end{array}$ & $\begin{array}{l}\text { - } \text { autosomal recessive } \\
\text { - } 9 \mathrm{q} 13-\mathrm{q} 21 \\
\text { - Frataxin }\end{array}$ \\
\hline
\end{tabular}




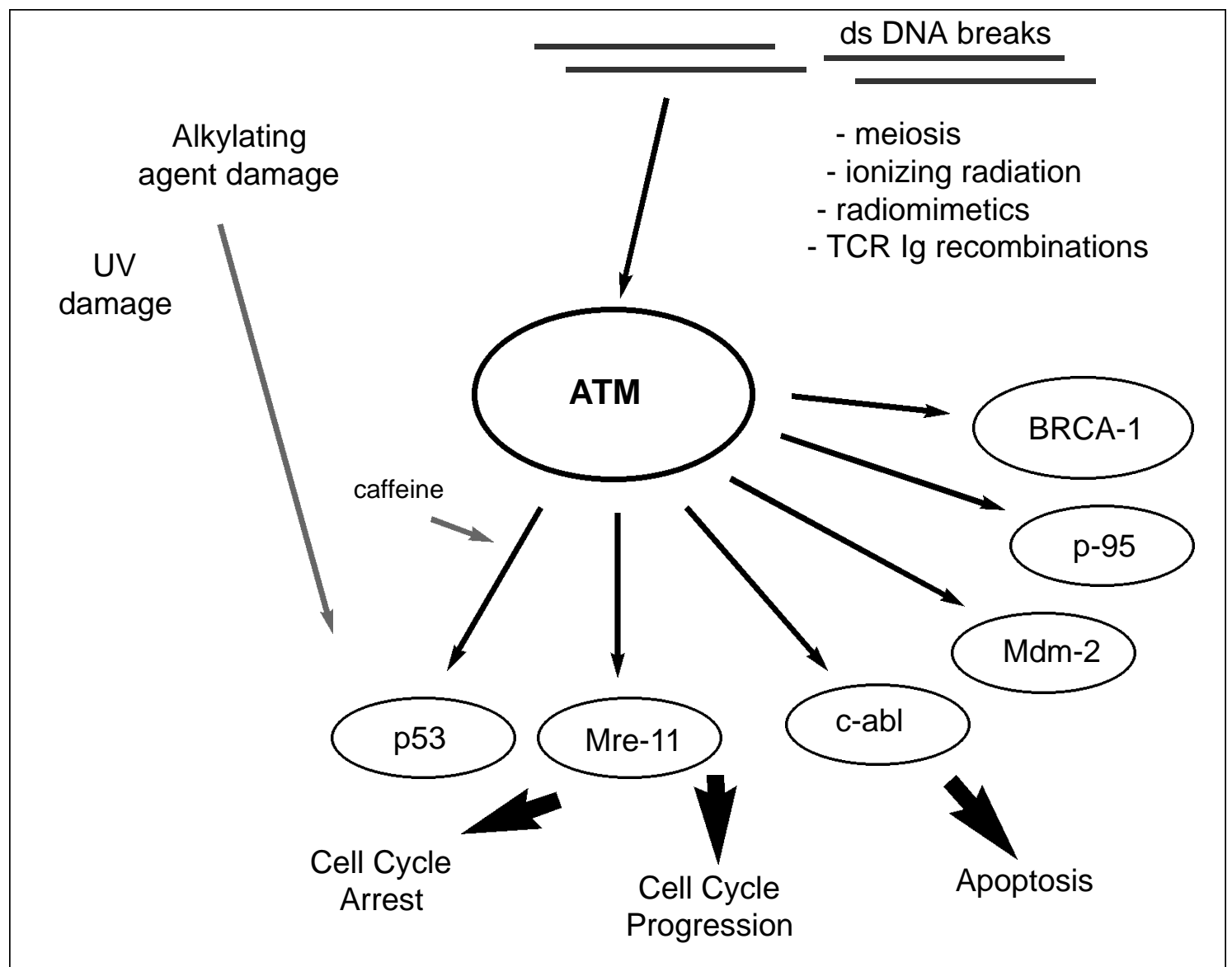

Figure 2: Schematic Representation of ATM Intracellular Role and some of its Putative Phosphorylation Targets. Double strand (ds) DNA breaks activate ATM protein, the ATM gene product. Through its kinase activity ATM in turn phosphorylates several substrates including p53, Mre-11, p95, c-abl, Mdm-2 and Brca-1 at the indicated serine site. The interaction of these molecules then likely determines the fate of the cell: apoptosis vs cell cycle arrest vs cell cycle progression. The precise mechanism by which ds DNAbreaks are sensed is unclear. Other forms of DNAdamage (alkylation, UV induced damage) also lead to the activation by phosphorylation of p53 but by an ATM independent pathway. The phosphorylation of 553 by ATM can be blocked by caffeine.

related, rad3-related). Using antibodies to either ATR or ATM, it has been possible to show that these two homologous molecules form part of synaptonemal complexes during meiosis. ${ }^{46}$

Current observations suggest that ATM directly activates p53 on the serine 15 residue when cells are subjected to a DNA damaging agent such as ionizing radiation. Activation of p53, labeled the "guardian of the genome" is a pivotal event in determining which of three potential outcomes a cell may take: cell cycle arrest, cell cycle progression or apoptosis. ${ }^{47,48}$ ATM also phosphorylates c-abl, another protein kinase implicated in the growth arrest response to DNA damage. ${ }^{49,50}$ Other ATM targets include BRCA1, p95, mdm2, Mre11 as well as the $\mathrm{IkB} \alpha$ subunit of NF-kB, implicated in various stress and apoptotic responses (see Figure 2). ${ }^{51-55}$ In addition, ATM itself appears to be a target of the caspase cascade that implements the apoptotic process. $^{56}$

Collating all this information still leaves an incomplete picture of ATM function (Figure 2). On the basis of comparative analysis, it seems probable that ATM is involved in regulating numerous cell cycle checkpoints and apoptosis in response to damage to DNA. All the pathways found to be defective in AT are functional when triggered by stimuli other than ionizing radiation. This suggests that the ATM mediated mechanism depends on an ability to "sense" the presence of double-strand DNA damage and mediate an appropriate response. This inability to process double-strand breaks correctly would account for aberrant meiosis in ATM-1-mice, T-cell receptor and immunoglobulin gene rearrangements, somatic recombination and the response to DNAdamaging agents. However, it still does not help in generating a unifying model that will explain all the seemingly diverse clinical features of the AT syndrome. Hence, although much has been learned in the five years since the gene was cloned and sequenced, the full role of the ATM protein within the cell is still incompletely defined and why its absence generates the AT phenotype remains unclear.

\section{ATM deficient mice}

ATM "knockout mice" have provided additional information about the role of ATM. ${ }^{57}$ The murine equivalent maps to chromosome $9 .{ }^{58}$ In many respects, the phenotype of ATM 
knockout mice is remarkably analogous to the human condition. They show severe gastrointestinal and salivary mucosal consequences to $4 \mathrm{G}$ of in vivo ionizing radiation, a dose welltolerated by normal mice. This sensitivity is also displayed in vitro. Within four months of birth, all mice develop malignant thymic lymphomas. On the other hand, although these mice display subtle motor dysfunction, as evaluated by rota rod, open field and gait analysis, they do not exhibit the progressive ataxia characteristic of the human condition. Neither do they exhibit the cerebellar degeneration and loss of Purkinje cells that is characteristic of AT. ${ }^{59-63}$ This may partly be accounted for by the limited life expectancy of these mice but likely also reflects some genetic redundancy that allows alternate bypass of crucial signaling pathways.

Attempts have been made to further characterize the mechanism of neuro-degeneration in the human brain. The loss of Purkinje cells seems to occur by the process of apoptosis but the underlying trigger is elusive. Northern blotting of human and murine samples has demonstrated that ATM message is not limited to the cerebellum but is ubiquitously distributed in brain tissue; amygdala, caudate, corpus callosum, thalamic nuclei hippocampus. ${ }^{62}$ In the developing human brain, ATM protein can be demonstrated in the cerebellar but not cerebral cortex at the late gestational stage, but the cerebellar degeneration associated with AT seems not to occur until well after birth. Only the migration of ectopic Purkinje cells suggests an earlier pathogenesis. Immunohistochemistry has shown immunereactivity of ATM mainly in the cytoplasm of Purkinje cells during late prenatal and early postnatal periods. However, ATM has also been detected in the locus coeruleus, substantia nigra and inferior olive as well as in the bronchial epithelium and developing testes, but reliable antibodies to human ATM are still not available. ${ }^{63}$

\section{MolecUlar Diagnosis}

Identification of the ATM gene has made diagnosis of the condition more certain. However, screening for ATM mutations is still impractical, as more than 400 mutations have been documented to date and they are spread over the entirety of this large gene. ${ }^{37,38}$ To confirm a clinical diagnosis, a sequential approach is suggested using: (a) the serum alpha fetoprotein level (elevated in $90 \%$ of AT patients), followed by (b) the protein truncation tests (PTT) which will detect $70 \%$ of ATM mutations. Western blotting, (c) will show little or absent ATM protein in $85 \%$ of patients and colony survival assay, (d) will confirm the radio-sensitivity in $>95 \%$ of AT patients. ${ }^{64}$ When only DNA is available, (e) specific mutations can be detected using the mega-single stranded conformational polymorphism (SSCP) technique. When these tests are used sequentially, the estimated rate of missing a diagnosis of AT is about $1 \%$.

\section{AT VARIANTS AND NIJMEGEN BREAKAGE SYNDROME}

The Nijmegen Breakage Syndrome (NBS) had its origins in the cytogenetics laboratory when Weemaes et $\mathrm{al}^{65}$ noted multiple chromosomal rearrangements involving chromosomes 7 and 14 in two siblings of consanguineous Dutch parents. Although this finding was almost pathognomonic of AT, the patients had neither ataxia nor telangiectasia. Nor did they resemble any of the other hereditary chromosome breakage syndromes, such as Bloom's or Fanconi's anemia. Thus, it was given its own name. NBS children are microcephalic and mentally retarded and the females do not mature after puberty. Nonetheless, AT and NBS share radiosensitivity (as measured by colony survival assay (CSA) or radioresistant DNA synthesis (RDS), immunodeficiency, increased cancer risk, translocations of chromosomes 7 and 14, and absent or atrophic thymus. In 1989, Curry et al ${ }^{66}$ described twins with all the symptoms of both syndromes; this was called ATFresno. Later, a German Breakage Syndrome (GBS) with many similar findings was described ${ }^{67}$ but now including anal atresia and occasional limb defects.

When Jaspers et $\mathrm{a}^{68}$ noted that RDS was abnormal in all four of the above syndromes, he attempted to analyze how many genes might be involved. Their data indicated that while some AT fibroblast strains did not complement one another, the NBS, GBS and ATFresno strains complemented all AT cells, but not one another. The latter three were subsequently referred to as "AT variants". Once the AT gene was fine mapped at chromosome 11q22-q23, it became clear that NBS and GBS did not link to this region of the genome. ATFresno, in contrast, did link to this region. Once the ATM gene was isolated, ${ }^{36}$ ATM mutations were found in ATFresno patients, ${ }^{69}$ but not in NBS or GBS patients. NBS was linked to $8 \mathrm{q} 21^{70,71}$ and NBS-1 was isolated shortly thereafter - again by positional cloning. ${ }^{72}$ Both NBS and GBS patients had mutations in the NBS-1 (p95) gene and are today considered to be the same disorder. The overlap of clinical phenotype between AT and NBS are due to the fact that ATM phosphorylates nibrin.

\section{Clinical management}

Management of the AT patient, once the diagnosis has been made, poses many problems. There is no effective therapy for slowing the progression of the ataxia. However, some interventions are clearly of benefit. Since the greatest mortality is caused by sino-pulmonary infections, prompt treatment with antibiotics, especially to cover aspiration pneumonia, is recommended. Some AT patients are placed on prophylactic antibiotics. In addition, intravenous gamma globulin is used in several AT centres. However, there have been no clinical trials to document the benefit of these therapies. The single most important supportive therapy for AT patients is aggressive physical therapy. This will help prevent the development of contractures later in life.

Given the cancer predisposition, early detection of any underlying malignancy is paramount. This can be accomplished by aggressive screening protocols, which may include annual or six monthly full physical examinations, complete blood counts and the monitoring of serum tumour markers. Once detected, special consideration must be made in the choice of treatment for such malignancies. For example, the use of ionizing radiation must be avoided if possible. Agents that are myo- and neurotoxic such as vincristine, vinblastine and the taxols must be minimized. Topoisomerase inhibitors should also be avoided since they also have an increased risk of inducing secondary malignancies. ${ }^{73,74}$

Although oxidative stress has been put forward as the mechanism underlying cerebellar degeneration in AT, courses of antioxidants have failed to halt the progressive nature of the 
disease. ${ }^{75}$ Despite this, Vitamin $\mathrm{E}$ and alpha lipoic acid are recommended, as is folic acid because it reduces chromsomal breaks and may prevent cancer causing translocations and inversions. $^{76}$

A small trial reported at the 8th International Workshop on AT in 1999, looked at the use of L-dopa in treating the neurological symptoms of $\mathrm{AT}^{73}$ Although there was no benefit in the ataxic symptoms, there was a trend to benefit in extrapyramidal symptoms in young patients. Further work is needed in this area. Partial success of treating Parkinson's Disease with human fetal transplants has raised hopes that a similar approach might be successful in ATbut at present there is no immediate promise of successful treatment of AT with neural transplantation.

\section{AT HETEROZYGOTES, GENETIC COUNSELING AND PRENATAL DIAGNOSIS}

\section{Heterozygotes}

Although AT carriers, i.e. AT heterozygotes, have no obvious clinical manifestations, two vexing issues complicate their health care. The first is the matter of cancer predisposition - in particular, the much publicized relationship to breast cancer. For over twenty years, epidemiological evidence has suggested that AT heterozygotes have a three to five-fold increased risk of developing breast cancer. $^{77-81}$ To date, there has been no molecular evidence to confirm this in any breast cancer population $^{82-85}$ but this issue is currently unresolved. The second matter is that of radiation sensitivity in the AT heterozygote. Although in vitro studies show that AT cells display an intermediate degree of radiation sensitivity, ${ }^{86-88}$ there is no confirmation to date that this has clinical correlates. Nevertheless, there is some evidence that mice heterozygous for the ATM knockout gene may display a delayed radiation sensitivity. ${ }^{89}$ It has been suggested that judicial minimization of radiation-based investigations of carriers is warranted. In the case of mammograms, the potential increased cancer risk from this low dose of radiation must be compared with the proven reduction in mortality from breast cancer by screening the over50 population, ${ }^{90}$ a population that must include $\sim 1 \%$ AT heterozygotes. At present, it would seem that female carriers over the age of 50 years will benefit from regular mammography.

\section{Prenatal diagnosis}

Prenatal diagnosis of AThas been available since $1993 .{ }^{91}$ This became possible by haplotype analysis once the gene had been clearly localized to chromosome 11q22-23. ${ }^{34}$ Today, the genetic markers used to define familial haplotypes are all within $<1 \mathrm{cM}$ of the gene, thus minimizing the recombination fraction to $<1 \%$. However, prenatal testing by haplotyping requires DNA from a prior affected child, one with a bona fide diagnosis of AT. In some families in whom the mutations have been clearly defined, prenatal diagnosis is also possible by direct identification of those carrying mutations. However, since most AT patients are compound heterozygotes, (i.e they carry two different mutations within the ATM gene) mistakes can be made. In addition, because different mutations require a slightly different laboratory protocol and many polymorphisms are present that may be misinterpreted as mutations, it is best to use haplotyping always with the same markers to follow the affected chromosomes. The use of chromosome breakage or RDS studies is not recommended.

\section{ConClusion}

Ataxia telangiectasia is a syndrome with pleiotropic manifestations that is inherited in an autosomal recessive manner. Great strides have been made in understanding the genetic basis of this disease in the last five years but there are still no therapeutic interventions to date that will abrogate the progressive neurological degeneration. Although we do not understand the precise molecular pathophysiology of AT, our comprehension of the genetic defect has allowed for prenatal diagnosis, genetic counseling and molecular confirmation of the clinical diagnosis. While some of the molecular pathways regulated by ATM are understood, the pathways by which ATM causes the many manifestations of AT, especially the cerebellar degeneration, remain to be clarified. Current AT research is focusing on defining the precise means by which CNS cells die, analyzing the phenotype of heterozygous knockout mice and studying the association between ATM mutations, breast cancer and lymphoproliferative disease. It is hoped that further advances will help to clarify the risk of malignancy to AT heterozygotes and also translate into useful therapeutic interventions for AT patients.

\section{REFERENCES}

1. Syllaba L, Henner K. Contribution a l'independence de l'athetose double idiopathique et congenitale. Rev Neurol 1926; 1: 541-562.

2. Louis Barr D. Sur un syndrome progressif comprenent des telangiectasies capillaires cutanees et conjonctivales symetriques, a disposition naevoide et des troubles cerebelleux. Confin Neurol 1941; Vol IV(Fasc 1/2): 32-42.

3. Boder E, Sedgwick RP. Ataxia Telangiectasia; a familial syndrome of progressive cerebellar ataxia, oculocutaneous telangiectasis and frequent pulmonary infection. Pediatrics 1958; 21: 526-554.

4. Paterson MC, Smith PJ. Ataxia telangiectasia; an inherited human disorder involving hypersensitivity to ionizing radiation and related DNA-damaging chemicals. Ann Rev Genet 1979; 13: 291-318.

5. Swift M, Morrell D, Cromartie E, et al. The incidence and gene frequency of ataxia-telangiectasia in the United States. Am J Hum Genet 1986; 39(5): 573-583.

6. Boder E. Ataxia telangiectasia; an overview. In: Gatti RA, Swift M eds. Ataxia Telangiectasia; Genetics, Neuropathology and Immunology of a Degenerative Disease of Childhood. New York: Alan R Liss, 1985: 1-63.

7. Aicardi J, Barbosa C, Andermann E, et al. Ataxia-ocular motor apraxia; a syndrome mimicking ataxia-telangiectasia. Ann Neurol 1988; 24(4): 497-502.

8. Gatti RA, Boder E, Vinters HV, et al. Ataxia Telangiectasis; an interdisciplinary approach to pathogenesis. Medicine 1991; 70 (No2): 99-117.

9. Wong V, Yu YL, Chan-Lui WY, Woo E, Yeung CY. Ataxia telangiectasia in Chinese children. A clinical and electrophysiological study. Clin Neurol Neurosurg 1987; 89(3):137-144.

10. Barbieri F, Santoro L, Crisci C, et al. Is the sensory neuropathy in ataxia telangiectasia distinguishable from that in Friedreich's ataxia? Morphometric and ultrastructural study of the sural nerve in a case of Louis Bar syndrome. Acta Neuropathol 1986; 69(34): $213-219$.

11. Harding AE. The inherited ataxias. Adv Neurol 1988; 48: 37-46.

12. Cabana MD, Crawford TO, Winkelstein JA, Christensen JR, Lederman HM. Consequences of the delayed diagnosis of ataxia telangiectasia. Pediatrics 1998; 102(1):98-100.

13. Chung EO, Bodensteiner JB, Noorani PA, Schochet SS. Cerebral 
white-matter changes suggesting leukodystrophy in ataxia telangiectasia. J Chil Neurol 1994; 9:31-35.

14. Waldman TA Broder S, Goldman CK, et al. Disorders of B cells and helper $\mathrm{T}$ cells in the pathogenesis of the immunoglobulin deficiency of patients with ataxia telangiectasia. J Clin Invest 1983; 71: 282-295.

15. Peterson RD, Cooper MD, Good RA. Lymphoid tissue abnormalities associated with ataxia telangiectasia. Am J Med 1966; 41(3): 342-359.

16. Epstein WL, Fudenberg HH, Reed WB, Boder E, Sedgwick RP. Immunologic studies in ataxia telangiectasia. I. Delayed hypersensitivity and serum immune globulin levels in probands and first-degree relatives. Int Arch Allergy Appl Immunol 1966; 30(1): 15-29.

17. Ito M, Nakagawa A, Hirabayashi N, Asai J. Bronchiolitis obliterans in ataxia telangiectasia. Virchows Arch 1997; 430(2);131-137

18. Woods SC, Taylor AMR. Ataxia telangiectasia in the British Isles; the clinical and laboratory features of 70 affected individuals. Quart J Med, 1992; 82: 169-179.

19. Spector BD, Filipovich AH, Perry GS, Kersey KS. Epidemiology of cancer in ataxia telangiectasia. In: Bridges BA, Hardnen DG, eds. Ataxia Telangiectasia - A Cellular and Molecular Link Between Cancer, Neuropathology and Immune Deficiency. Chichester: Wiley, 1982: 103.

20. Morrell D, Chase CL, Swift M. Cancers in 44 families with ataxia telangiectasia. Cancer Genet Cytogenet 1990; 50: 119-123.

21. Taylor AM. Leukemia and lymphoma in ataxia telangiectasia. Blood 1996; 87(2): 423-38.

22. Morgan JL, Holcomb TM, Morrisey RW. Radiation reaction in ataxia telangiectasia. Am J Dis Child 1968; 116: 557-558.

23. Cunliffe PN, Mann JR, Cameron AH, Roberts KD, Ward HWC. Radiosensitivity in ataxia telangiectasia. Br J Radiol 1975; 48: 374-376.

24. Sardanelli F, Parodi RC, Ottonello C, et al. Cranial MRI in ataxia telangiectasia. Neuroradiology 1995; 37(1): 77-82.

25. Paula-Barbosa MM, Ruela C, Tavares MA, et al. Cerebellar cortex ultrastructure in ataxia telangiectasia. Ann Neurol 1983; 13(3): 297-302

26. Aguilar MJ, Kamoshita S, Landing BH, Boder E, Sedgwick RP. Pathological observations in ataxia telangiectasia. A report of five cases. J Neuropathol Exp Neurol 1968; 27(4); 659-676.

27. Perry TL, Kish SJ, Hinton D, et al. Neurochemical abnormalities in a patient with ataxia telangiectasia. Neurology 1984; 34: 187191.

28. Dunn HG, Meuwissen H, Livingstone CS, Pump KK. Ataxia Telangiectasia. Can Med Assoc J 1964; 91: 1106-1118.

29. Vinters HV, Gatti RA, Rakic P. Sequence of cellular events in cerebellar ontogeny relevant to expression of neuronal abnormalities in ataxia telangiectasia. In: Gatti RA, Swift M, eds. Ataxia Telangiectasia; Genetics, Neuropathology and Immunology of a Degenerative Disease of Childhood. New York: Alan R Liss, 1985: 233-255.

30. Blocher D, Sigut D, Hannan MA. Fibroblasts from ataxia telangiectasia(AT) and AT heterozygotes show an enhanced level of residual DNAdouble strand breaks after low dose-rate gamma radiation as assayed by pulsed field gel electrophoresis. Int $\mathbf{J}$ Radiat Biol 1991; 60(5): 791-802.

31. Coquerelle TM, Weibezahn KF, Lucke-Huhle C. Rejoining of double strand breaks in normal human and ataxia telangiectasia fibroblasts after exposure to 60Co gamma rays, 241Am alpha particles or bleomycin. Int J Radiat Biol Relat Stud Phys Chem Med 1987; 51(2): 209-218.

32. Murnane JP, R B Painter. Complementation of the defects of DNA synthesis in irradiated and unirradiated ataxia telangiectasia cells. Proc Natl Acad Sci USA1982; 79: 1960-1963.

33. Jaspers NG, Painter RB, Paterson MC, Kidson C, Inoue $T$. Complementation analysis of ataxia telangiectasia. Kroc Found Ser $1985 ; 19: 147-262$

34. Gatti RA, Berkel I, Boder E, et al. Localization of an ataxia telangiectasia gene to chromosome 11q22-23. Nature 1988; 336: 577-580.

35. Lange E, Borresen AL, Chen X, et al. Localization of an ataxia- telangiectasia gene to an approximately $500-\mathrm{kb}$ interval on chromosome 11q23.1: linkage analysis of 176 families by an international consortium. Am J Hum Genet. 1995;57(1):112-9.

36. Savitsky K, Bar-Shira A, Gilad S, et al. A single ataxia telangiectasia gene with a product similar to PI-3 kinase. Science 1995; 268: 1749-1753.

37. Gilad S, Khosravi R, Shkedy D, et al. Predominance of null mutations in ataxia telangiectasia. Hum Mol Genet 1996; 5 (4): 433-439.

38. Concannon P, Gatti RA. Diversity of ATM gene mutations detected in patients with ataxia telangiectasia. Hum Mutat 1997; 10(2): 100-107.

39. Castellvi-Bel S, Sheikhavandi S, Telatar M, et al. New mutations, polymorphisms, and rare variants in the ATM gene detected by a novel SSCPstrategy. Hum Mutat 1999; 14: 156-162.

40. Telatar M, Teraoka S, Wang Z, et al. Ataxia telangiectasia; identification and detection of founder mutations in the ATM gene in ethnic populations. Am J Hum Genet 1998; 62: 86-97.

41. Teraoka S, Telatar M, Becker-Catania S, et al. Splicing defects in the ataxia telangiectasia gene, ATM; underlyinig mutations and phenotypic consequences. Am J Hum Genet 1999; 64:16171631.

42. Yao R, Cooper GM. Requirement for phosphatidylinositol-3 kinase in the prevention of apoptosis by nerve growth factor. Science 1995; 267: 2003-2006.

43. Lavin MF, Khanna KK, Beamish H, et al. Relationship of the ataxia telangiectasia protein ATM to phosphoinositide 3-kinase. Trends Biochem Sci 1995; 20(10): 382-383.

44. Greenwell PW, Kronmal SL, Porter SE, et al. TEL1, a gene involved in controlling telomere length in S cerevisiae, is homologous to the human ataxia telangiectasia gene. Cell 1995; 82: 823-829.

45. Hari KL, Santerre A, Sekelsky JJ, et al. The mei-41 gene of D melanogaster is a structural and functional homolog of the human ataxia telangiectasia gene. Cell 1995; 82: 815-821.

46. Keegan KS, Holtzman DA, Plug AW, et al. The Atr and Atm protein kinases associate with different sites along meiotically pairing chromosomes. Genes Dev 1996; 10(19):2423-2437

47. Jung M, Lee S, Zhang Y, Dritschilo A. Regulation of p53 in response to ionizing radiation in ataxia telangiectasia fibroblasts. Int J Radiat Oncol Biol Phys 1997; 37 (2): 417-422.

48. Canman CE, Lim DS, Cimprich KA, et al. Activation of the ATM kinase by ionizing radiation and phosphorylation of p53. Science. 1998; 281:1677-1679.

49. Baskaran R, Wood LD, Whitaker LL, et al. Ataxia telangiectasia mutant protein activates c-Abl tyrosine kinase in response to radiation. Nature 1997; 387: 516-519.

50. Shafman T, Khanna KK, Kedar P, et al. Interaction between ATM protein and c-Abl in response to DNAdamage. Nature 1997; 387: 520-523.

51. Kim ST, Lim DS, Canman CE, Kastan MB. Substrate specificities and identification of putative substrates of ATM kinase family members. J Biol Chem 1999;274(53):37538-43

52. Dasika GK, Lin SC, Zhao S, et al. DNAdamage-induced cell cycle checkpoints and DNA strand break repair in development and tumorigenesis. Oncogene 1999;18(55):7883-7899

53. Khosravi R, Maya R, Gottlieb T, et al. Rapid ATM-dependent phosphorylation of MDM2 precedes p53 accumulation in response to DNAdamage. Proc Natl Acad Sci USA1999; 96(26): 14973-14977.

54. Piret B, Schoonbroodt S, Piette J. The ATM protein is required for sustained activation of NF-kappaB following DNA damage. Oncogene 1999; 18(13): 2261-2271.

55. Gatei M, Young D, Cerosaletti KM, et al. ATM-dependent phosphorylation of nibrin in response to radiation exposure. Nat Genet. 2000;25(1):115-9.

56. Watters D. Molecular mechanisms of ionizing radiation-induced apoptosis. Immunol Cell Biol 1999; 77(3): 263-271.

57. Herzog KH, Chong MJ, Kapsetaki M, Morgan JI, McKinnon PJ. Requirement for ATM in ionizing radiation-induced cell death in the developing central nervous system. Science 1998; 280: 10891091

58. Xia Y,Welch CL, Warden CH, et al. Assignment of the mouse ataxia 
telangiectasia gene (ATM) to mouse chromosome 9. Mamm Genome 1996; 7(7): 554-555.

59. Barlow C, Hirotsun S, Paylor R, et al. ATM-deficient mice; a paradigm of ataxia telangiectasia. Cell 1996; 86: 159-171.

60. Elson A, Wang Y, Daugherty CJ, et al. Pleiotropic defects in ataxia telangiectasia protein-deficient mice. Proc Natl Acad Sci USA 1996; 93(23): 13084-13089.

61. Eilam R, Peter Y, Elson A ,et al. Selective loss of dopaminergic nigro-striatal neurons in brains of ATM-deficient mice. Proc Natl Acad Sci USA1998; 95(21): 12653-12656

62. Soares HD, Morgan JI, McKinnon PJ ATM expression patterns suggest a contribution from the peripheral nervous system to the phenotype of ataxia telangiectasia. Neuroscience 1998; 86(4): $1045-1054$

63. Oka A, Takashima S. Expression of the ataxia telangiectasia gene (ATM) product in human cerebellar neurons during development. Neurosci Lett 1998; 252(3): 195-198.

64. Huo YK, Wang Z, Hong J-H, et al. Radiosensitivity of ataxia telangiectasia, X-linked agammaglobulinemia and related syndromes. Cancer Res 1994; 54: 2544-2547.

65. Weemaes CMR, Hustinx TWJ, Scheres JMJC, et al. A new chromosomal instability disorder; the Nijmegen breakage syndrome. Acta Paediatr Scand 1981; 70: 557-562.

66. Curry CJR, O'Lague P, Tsai J, et al. ATFresno: a phenotype linking ataxia telangiectasia with the Nijmegen breakage syndrome. Am J Hum Genet 1989; 45: 270-275.

67. Wegner RD, Metzger M, Hanefeld NG, et al. A new chromosomal instability disorder confirmed by complementation studies. Clin Genet 1988; 33: 20-32.

68. Jaspers NGJ, Gatti RA, Baan C, Linssen PCML, Bootsma D. Genetic complementation analysis of ataxia telangiectasia and Nijmegan breakage syndrome; a survey of 50 patients. Cytogenet Cell Genet 1988; 49: 259-263.

69. Gilad S, Chessa L, Khosravi R, et al. Genotype-phenotype relationships in ataxia telangiectasia and variants. Am J Hum Genet 1998; 62: 551-561.

70. Saar K, Chrzanowska KH, Stumm M, et al. The gene for the ataxia telangiectasia variant, Nijmegen Breakage Syndrome, maps to a 1-cM interval on chromosome 8q21. Am J Hum Genet 1997; 60: 605-610.

71. Cerosaletti KM, Lange E, Stringham HM, et al. Fine localization of the Nijmegen Breakage Syndrome gene to 8q21; evidence for a common founder haplotype. Am J Hum Genet 1998; 63: 125134.

72. Varon R, Vissinga C, Platzer M, et al. Nibrin, a novel DNAdoublestrand break repair protein, is mutated in Nijmegen Breakage Syndrome. Cell 1998; 93: 467-476.

73. Lavin MF, Concannon P, Gatti RA. Eighth International Workshop on ataxia telangiectasia (ATW8). Cancer Res 1999; 59: 38453849.

74. Sandoval C, Swift M. Treatment of lymphoid malignancies in patients with ataxia telangiectasia. Med Pediatr Oncol 1998; 31(6): 491-497.

75. Pagano G, Korkina LG, Brunk UT, et al. Congenital disorders sharing oxidative stress and cancer proneness as phenotypic hallmarks; prospects for joint research in pharmacology. Med Hypotheses 1998; 51(3): 253-266.

76. Perlman, SL. Treatment of ataxia telangiectasia. In: Gatti RA, Painter RB, eds. Ataxia Telangiectasia. Heidelberg: SpringerVerlag. 1993:269-278.

77. Athma P, Rappaport R and Swift M. Molecular genotyping shows that Ataxia Telangiectasia heterozygotes are predisposed to breast cancer. Cancer Genet Cytogenet 1996;92:130-134.

78. Swift M, Reitnauer PJ, Morrell D, Chase CL. Breast and other cancers in families with Ataxia telangiectasia. New Eng J Med 1987; 316: 1289-1294.

79. Pippard EC, Hall AJ, Barker DJ, Bridges BA. Cancer in homozygotes and heterozygotes of ataxia telangiectasia and xeroderma pigmentosum in Britain. Cancer Res 1988; 48: 29292932.

80. Swift M. Ionizing radiation, breast cancer, and ataxia telangiectasia. J Natl Cancer Inst 1994; 86 (21): 1571-1572.

81. Swift M, Morrell D, Massey RB, Chase CL. Incidence of cancer in 161 families affected by ataxia telangiectasia. New Eng J Med 1991; 325: 1831-1836.

82. Fitzgerald MG, Bean JM, Hegde SR, et al. Heterozygous ATM mutations do not contribute to early onset of breast cancer. Nature Genet 1997; 15: 307-310.

83. Ramsay J, Birrell G, Lavin M. Testing for mutations of the ataxia telangiectasia gene in radiosensitive breast cancer patients. Radiother Oncol 1998; 47(2): 125-128.

84. Bebb G, Zhe Yu, Jian Chen, et al. Absence of mutations in the ATM gene in forty-seven cases of sporadic breast cancer. Br J Cancer 1999; 80: 1979-1981.

85. Appleby JM, Barber JB, Levine E, et al. Absence of mutations in the ATM gene in breast cancer patients with severe responses to radiotherapy. Br J Cancer 1997; 76(12): 1546-1549.

86. Paterson MC, Anderson AK, Smith BP, Smith PJ. Enhanced radiosensitivity of cultured fibroblasts from ataxia telangiectasia heterozygotes manifested by defective colony-forming ability and reduced DNA repair replication after hypoxic gammairradiation. Cancer Res 1979; 39: 3725-3734.

87. Scott D, Spreadborough AR, Roberts SA. Radiation-induced $\mathrm{G}_{2}$ delay and spontaneous chromosome aberrations in ataxia telangiectasia homozygotes and heterozygotes. Int J Radiat Biol 1994; 66; S157-163.

88. Bebb DG, Steele PP, Warrington PJ, Moffat JA, Glickman BW. Caffeine does not potentiate gamma-radiation induced DNA damage in ataxia telangiectasia lymphoblastoid cells. Mutat Res 1998; 401: 27-32.

89. Barlow C, Eckhaus MA, Schaffer AA, Wynshaw-Boris A. ATM haploinsufficiency results in increased sensitivity to sublethal doses of ionizing radiation in mice. Nature Genet 1999; 21(4): 3593-60.

90. Kerlikowske K. Efficacy of screening mammography among women aged 40 to 49 years and 50 to 69 years; comparison of relative and absolute benefit. J Natl Cancer Inst Monogr 1997, 22: 79-86.

91. Gatti RA, Peterson KL, Novak J, et al. Prenatal genotyping of ataxia telangiectasia. Lancet 1993; 342: 376. 